\title{
ERIUGENY ONTOLOGICZNA KONCEPCJA RZECZYWISTOŚCI
}

\begin{abstract}
Streszczenie. W 2009 roku Benedykt XVI podczas audiencji generalnej zaproponował krótkie rozważanie dotyczące myśli Jana Szkota Eriugeny, którego poglądy zostały czterokrotnie potępione. Filozofia Eriugeny bywała w historii najczęściej ujmowana jako sprzeczna z chrześcijaństwem panteistyczna wizja rzeczywistości lub patrystyka i chrześcijański neoplatonizm. Artykuł jest próbą ukazania ontologicznej wizji rzeczywistości, którą Eriugena zaproponował w ramach autorskiego systemu filozoficznego. Zgodnie z wynikami rozważań nad zaproponowanym przez filozofa podziałem rzeczywistości na byt i niebyt oraz przyjętym kryterium podziału, artykuł stanowi również próbę analizy, czym ten podział skutkuje dla takich kategorii, jak Bóg, przyczyny rzeczy, człowiek, rzeczy zmysłowe i materia. Poglądy Eriugeny przeniknęły do europejskiej filozofii i w sposób ukryty oddziaływały, choć nie zostały w pełni docenione, a sam filozof nie został właściwie zrozumiany.
\end{abstract}

Słowa kluczowe: Bóg, Eriugena, byt, niebyt, Benedykt XVI, ontologia

1. Wstęp. 2. Problem bytu i niebytu. 3. Wybrane kategorie w ontologicznym podziale.

4. Zakończenie.

\section{WSTĘP}

10 czerwca 2009 roku Benedykt XVI zaproponował zgromadzonym na audiencji generalnej wspomnienie Jana Szkota Eriugeny - filozofa, którego poglądy zostały potępione przez dwóch papieży i dwa synody. Jedenaście wieków i 54 lata minęły od pierwszych potępień do audiencji, podczas której papież wypowiedział znamienne słowa: „Dzisiaj pragnę mówić o Janie Szkocie Eriugenie, wybitnym myślicielu chrześcijańskiego Zachodu, o którego pochodzeniu wiemy niewiele"1.

1 Benedykt XVI, Jan Szkot Eriugena, Audiencja Generalna 10 czerwca 2009 roku, L'Osservatore Romano (2009)9(316). 
Celem niniejszego artykułu jest ukazanie ontologicznej wizji rzeczywistości, którą Eriugena zaproponował w ramach autorskiego systemu filozoficznego odczytywanego w historii filozofii najczęściej jako sprzeczna z chrześcijaństwem panteistyczna wizja rzeczywistości lub patrystyka i chrześcijański neoplatonizm. Poglądy Eriugeny przeniknęły do europejskiej filozofii i w sposób ukryty oddziaływały choć nie zostały w pełni docenione, a sam filozof nie został właściwie zrozumiany, na co Benedykt XVI zwraca uwagę w następujących słowach: „Prawdę mówiąc, dzieło teologiczne Jana Szkota nie cieszyło się wielkim powodzeniem. Jego dzieła popadły w zapomnienie nie tylko ze względu na koniec ery karolińskiej; cień na jego postać rzuciła również cenzura ze strony władzy kościelnej. Jan Szkot jest w rzeczywistości przedstawicielem radykalnego platonizmu, który niekiedy wydaje się bliski wizji panteistycznej, choć jego subiektywne intencje były zawsze ortodoksyjne"2.

\section{PROBLEM BYTU I NIEBYTU}

Bóg w systemie filozoficznym Jana Szkota Eriugeny jest Niebytem, ponieważ wymyka się ludzkiemu poznaniu. Człowiek nie jest w stanie poznać Boga z powodu Jego doskonałości. Niebytem jest również materia pierwsza, która także wymyka się poznaniu z uwagi na brak doskonałości. Ta ontologia jest ściśle związana z możliwościami poznawczymi człowieka, a podstawowym określeniem całej rzeczywistości - stworzonej i niestworzonej jest niezdefiniowane przez filozofa pojęcie natury ${ }^{3}$. Kryterium możliwości poznania czegoś przez człowieka wyznacza więc podział na byt i niebyt. Do kategorii niebytu zalicza się Stwórcę wszystkiego i wspomnianą już materię pierwszą, natomiast do bytu zalicza się ten obszar stworzenia, który nie wymyka się ludzkiemu poznaniu. Pojęcie natury rozciąga się

2 Tamże.

3 Zob. A. Kijewska, Neoplatonizm Jana Szkota Eriugeny, Lublin 1994, 105. 
na byt i niebyt. Eriugena proponuje pięć różnych sposobów rozróżnienia bytu i niebytu. W Periphyseonie pisze: „I tak to zasadnicze zróżnicowanie, które oddziela wszystkie rzeczy wymaga pięciu sposobów interpretacji. Wydaje się, że pierwszym $z$ nich jest ten, za którego sprawą rozum przekonuje, że o wszystkim, co podpada pod cielesny zmysł albo ujęcie inteligibilne, prawdziwie i zgodnie z rozumem orzeka się, że jest. To zaś, co z racji wzniosłości swojej natury wymyka się nie tylko ujęciu wszelkiego zmysłu, ale i wszelkiego intelektu i rozumu, słusznie wydaje się nie być, a co w sposób właściwy pojmowane jest jedynie w odniesieniu do samego Boga i materii oraz racji i istot wszystkich rzeczy, które przez Boga zostały stworzone"4. Pierwsze zróżnicowanie jest wyraźnym nawiązaniem do myśli Pseudo-Dionizego Aeropagity, co autor wprost potwierdza, wskazując na autorytet Dionizego, który podkreślał, iż Bóg jako jedyny istnieje prawdziwie i będąc istotą wszystkiego stanowi Bóstwo, które warunkuje istnienie wszystkiego - warunkuje byt będąc samo ponad bytem 5 .

W Homilii do Prologu Ewangelii Jana Eriugena pisze: „A jak powiada wielki Dionizy Aeropagita: »Bytem wszystkich rzeczy jest Bóstwo, które jest ponad bytem "'. Warto w tym miejscu zauważyć, że Eriugena był przekonany o apostolskim autorytecie Aeropagity, co

4 Eriugena, Periphyseon, Księga I, Kęty 2009, 63 oraz 62 za Eriugena, Periphyseon, liber primus, opracowany przez E. Jeauneau dla serii „Corpus Christianorum. Continuatio Mediaevalis” 161, Turnhout 1996: „Ipsa itaque primordialis omnium discretiva differentia quinque suae interpretationis modus inquirit. Quorum promus videtur esse ipse per quem ratio suadet omnia quae corporeo sensui vel intelligentiae perception succumbunt vere acrationabiliter dici esse, ea vero quae per excellentiam suae naturae non solum sensum sed etiam omnem intellectum rationemque fugiunt iure videri non esse, quae non nisi in solo deo et in omnium rerum quae ab eo condita sunt rationibus atque essentiis recte intelliguntur".

5 Zob. Pseudo-Dionizy Aeropagita, Hierarchia niebiańska IV, 1 w: Pisma teologiczne II, Kraków 1999, 62.

6 Eriugena, Komentarz do Ewangelii Jana z Homilią do Prologu Ewangelii Jana, Kęty 2000, 53. 
zostało w toku prowadzonych badań zakwestionowane. Nie uwłacza to jednak całkowicie temu myślicielowi, o czym może świadczyć np. audiencja generalna Benedykta XVI z dnia 14 maja 2008 roku? Pierwsze zróżnicowanie zostało potwierdzone przez Jana Szkota również w Homilii, gdzie filozof pisze: „Mówię zaś »to, co jest« o tym, co nie wymyka się całkowicie pojmowaniu człowieka czy anioła, gdyż znajduje się po Bogu, w liczbie tego, co zostało stworzone przez jedna Przyczynę wszystkich rzeczy. Tym zaś, »co nie jest «, jest zaiste to, co przekracza siły wszelkiego pojmowania"». Bóg, zdaniem Eriugeny, nie jest, bo przekracza w swej istocie możliwości i siły ludzkiego i każdego pojmowania. Bóg nie jest, ponieważ jest absolutnie nieskończony i nawet nie pojmuje sam siebie. Gdyby miał siebie pojać, to musiałby siebie zdefiniować, a gdyby siebie zdefiniował, to wówczas zakreśliłby swe granice. Bóg jest Niebytem, którego nic nie ogranicza, a który sam transcenduje wszystkie możliwe bytowe kategorie. Ten Niebyt sam jest źródłem wszelkiego bytu?

Charakterystyczna dla neoplatoników hierarchiczna wizja rzeczywistości staje się źródłem drugiego zróżnicowania bytu i niebytu. Wszystkie istniejące rzeczy podlegają pewnemu porządkowi. Każda rzecz ma swoje miejsce wśród różnych poziomów rzeczywistości. Afirmacja poziomu, o którym orzekany będzie byt, jest negacją wyższego poziomu, o którym orzeka się niebyt. Eriugena wyjaśnia ten podział w następujący sposób: „Przejdźmy zatem do drugiego sposobu pojmowania bytu i niebytu, który przejawia się w uporządkowaniu i zróżnicowaniu natur stworzonych. Rozpoczyna się on od najwznioślejszej i najbliżej Boga ustanowionej duchowej mocy i zstępuje aż do granicy racjonalnego i nieracjonalnego stworzenia, czyli - aby rzec bardziej otwarcie - idzie od najbardziej wyniesionego

7 Zob. Benedykt XVI, Pseudo-Dionizy Aeropagita, Audiencja Generalna 14 maja 2008 roku, L'Osservatore Romano (2008)6(304).

8 Eriugena, Komentarz z Homilia, dz. cyt., 45.

9 Zob. A. Kijewska, Neoplatonizm, dz. cyt., 111. 
bytu anielskiego aż ku najniższej części duszy racjonalnej i nieracjonalnej, czyli aż do tej zasady życia, która odżywia i sprawia wzrost, a która to część duszy jest najniższa, ponieważ odżywia ciało i powoduje jego wzrastanie. (...). Afirmacja bowiem porządku niższego jest negacją wyższego, i podobnie negacja porządku niższego jest afirmacją wyższego. A w ten sposób afirmacja porządku wyższego jest negacją niższego, negacja zaś wyższego jest afirmacją niższego" ${ }^{10}$. Wszystkie istoty podpadają pod zasadę tego podziału aż dochodzimy do porządku najwyższego, który kończy się ostatnią negacją, bo negacja jego samego jest niemożliwa, gdyż On sam nie potwierdza już niczego wyższego od siebie. Tak w drugim podziale Eriugena dochodzi do Boga który jest Niebytem - Negacją nie potwierdzająca już niczego wyższego. Wskazując znów na uwarunkowania poznawcze, Eriugena pisze: „Z tego też powodu, o każdym porządku racjonalnego i intelektualnego stworzenia orzeka się, że jest i że nie jest. Jest bowiem o tyle, o ile jest poznawany przez porządki wyższe albo przez siebie samego; nie jest zaś, o ile nie pozwala, by pojęły go te porządki, które są poniżej niego" ${ }^{11}$. Bóg jest więc Niebytem, ponieważ nie jest, bo nie pozwala, by pojęły Go niższe porządki. W tym kontekście materia pierwsza również jest niebytem, ponieważ zachodzi brak porządków niższych, które ewentualnie mogłyby ją poznawać

10 Eriugena, Periphyseon, Księga I, 65-67 oraz 64-66 za Periphyseon, liber primus: „Fiat igitur secundus modus, qui in naturarum creatarum ordinibus atque differentiis consideratur. Qui ab excelsissima et circa deum proxime constituta intellectuali virtute inchoans usque ad exteremitatem rationalis irrationalisque creature descendit, hoc est, ut apertius, a sublissimo Angelo usque ad extremam rationabilis irrationabilisque amine partem, nutritivam dico et auctivam vitam, quae pars amine ultima est, quoniam corpus nutrit et auget. (...). Inferioris enim affirmatio superioris est negatio. Itemque inferioris negatio superioris est affirmatio. Eodemque modo superioris affirmatio inferioris est negatio, negatio vero superioris erit affirmatio inferioris".

11 Tamże, 67 oraz 66 za Periphyseon, liber primus: „Hac item ratione omnis ordo rationalis et intellectualis creaturae esse dicitur et non esse. Est enim, quantum a superioribus vel a se ipso cognoscitur; non est autem, quantum ab infrerioribus se comprehendi non sinit". 
lub którym mogłaby ona na takie poznanie pozwalać. Trzecie zróżnicowanie bytu i niebytu jest uwarunkowane istnieniem w świecie $\mathrm{w}$ formie zaktualizowanej oraz potencjalnej. Bytem jest to, co istnieje $\mathrm{w}$ formie zaktualizowanej, natomiast niebyt można orzec o tym, co istnieje tylko potencjalnie i pozostaje ukryte w swych przyczynach. „Trzeci sposób rozumienia bytu i niebytu bardzo stosownie rozważa się w tych rzeczach, z których składa się pełnia tego widzialnego świata i w poprzedzających je przyczynach, które znajdują się w najtajniejszych załomach natury. Cokolwiek bowiem z tych przyczyn dzięki rodzeniu w materii i formie, daje się poznać w czasie i miejscu, o tym - zgodnie z pewnym ludzkim sposobem wyrażania się - orzeka się, że jest. Istotnie za sprawą tego wspomnianego wyżej, nawyku orzeka się, że nie jest o tym, co wciąż zawiera się w zakamarkach natury i nie ujawniło się ani w formie, ani w materii, w miejscu lub czasie czy w pozostałych przypadłościach"12.

Trzecie zróżnicowanie zostaje unaocznione w odwołaniu się do ludzkiej natury. Bóg już w pierwszym człowieku ustanowił wszystkich ludzi, lecz nie wszystkich wprowadził do widzialnej formy w określonym miejscu i czasie. Ludzie wchodzą w świat widzialny zgodnie z pewnym porządkiem ustanowionym przez Boga. O ludziach, którzy już pojawili się na świecie, można orzec, że są, natomiast o tych, którzy jeszcze się nie pojawili, można wciąż orzekać, że jeszcze nie są. Tak w jednej ludzkiej naturze mieści się znów byt i niebyt, mieszczą się ci, którzy są, i ci, którzy jeszcze nie są, choć będą. W tym kontekście ludzka natura podobna jest, zdaniem

12 Tamże, 67 oraz 66 za Periphyseon, liber primus: „Tertius modus non incongrue inspicitur in his quibus huius mundi visibilis plenitudo perficitur et suis causis praecedentibus in secretissimis naturae sinibus. Quicquid enim ipsarum causarum in materia et forma in temporibus et locis per generationem cognoscitur quadam humana consuetudine esse, quicquid vero adhuc in ipsis naturae sinibus continetur neque in forma vel materia loco vel tempore caeterisque accidentibus apparet eadem praedicta consuetudine dicitur non esse". 
Eriugeny, do mocy nasion, drzew rodzących owoce i zió $1^{13}$. Eriugena w Homilii pisze: „Zauważ w jaki sposób przyczyny wszystkich rzeczy, które mieści w sobie sfera tego świata podpadającego pod zmysły, istnieją jednocześnie na sposób jedności w owym słońcu, które bywa nazywane największym światłem świata. (...). Rozważ wieloraką i nieskończoną moc nasion: w jaki sposób tak wielka liczba ziół, owoców, zwierząt zawiera się jednocześnie w poszczególnych nasionach [i] w jaki sposób wyłania się z nich piękna i niedająca się zliczyć wielość form” ${ }^{14}$. Podobnie jak w Periphyseonie, również w Homilii autor unaocznia trzecie zróżnicowanie, wskazując na człowieka, który będąc jednym bytem, posiada liczne umiejętności i może stosować różne reguły. Trzecie zróżnicowanie nie dotyczy już bezpośrednio Boga, lecz raczej wydaje się odnosić tylko do stworzenia, a uwarunkowania poznawcze powodują, że również w tym obszarze mamy do czynienia $z$ bytami i niebytami. Przejście od niebytu do bytu jest ściśle związane $\mathrm{z}$ aktualizacją $\mathrm{w}$ rzeczywistości tego, co wcześniej jako niebyt pozostawało ukryte w swej przyczynie. Choć trzecie zróżnicowanie nie dotyczy Boga, to bezpośrednio nawiązuje do pierwszego $\mathrm{w}$ tym sensie, $\dot{z}$ e w pierwszym do niebytu zostały zaliczone również racje i istoty wszystkich rzeczy, a więc przyczyny wszystkich rzeczy, które zostają zaliczone do niebytu również w trzecim zróżnicowaniu. Rzecz będąca stworzeniem, dopóki znajduje się w swej przyczynie, należy, podobnie jak Stwórca, do niebytu. Po aktualizacji w świecie staje się bytem - stworzeniem, które można w jakiejś mierze poznać. Zarysowuje się tu pewien problem samych przyczyn które sytuują się po stronie stworzenia, lecz funkcjonują zawsze jako niebyty. Czasami zdają się być prawie jak Bóg, choć Bóg jest ich przyczyną i źródłem i daleko przewyższa absolutnie wszystko. Bóg poznał przyczyny, więc dla Boga są one bytami. Człowiek w sposób ograniczony może

13 Zob. tamże, 69.

14 Eriugena, Komentarz z Homilią, dz. cyt., 52. 
poznawać przyczyny, więc dla człowieka w tym zróżnicowaniu pozostają one niebytami.

W czwartym zróżnicowaniu bytu i niebytu następuje prawie całkowite uzależnienie tej ontologii od możliwości ludzkiego poznania. Nawiązując do koncepcji platońskich, według Eriugeny byt przysługuje tylko temu, co może zostać pojęte przez intelekt. Zgodnie $z$ nauką Platona świat materialny funkcjonuje w procesie ciągłej przemiany - powstaje, trwa w zmianie i ginie. Intelekt nie może niczego w tym świecie o tym świecie w sposób pewny pojąć, niczego poza atrybutem zmiany. Skoro intelekt nie pojmuje w sensie właściwym materialnej rzeczywistości, to należy ona do niebytu. W Timajosie Platon pisze: „Otóż według mego zdania należy przede wszystkim rozróżnić te dwie rzeczy. Coś, co istnieje wiecznie, a powstawania nie ma, i coś, co powstaje zawsze, a nie istnieje nigdy. Jedno rozumem, który ujmuje ściśle, uchwycić można jako zawsze takie samo, drugie mniemaniem z pomocą spostrzeżeń nieścisłych daje się uchwycić jako coś, co powstaje i ginie, a w rzeczywistości nie istnieje nigdy"15. Eriugena nawiązując do Platona pisze: „Czwartym sposobem jest ten, który - według filozofów - bardzo właściwie orzeka byt jedynie o tym, co pojmuje się samym intelektem. Niebytem zaś nazywa się zgodnie $z$ prawdą to, co na drodze rodzenia, za pomocą rozciągania lub kurczenia się materii, różnicuje się, łączy i rozwiązuje poprzez zmianę miejsca, jak i przestrzeni i czasu, jak to jest w przypadku wszystkich ciał, które mogą się rodzić i podlegać zniszczeniu"16. Według czwartego zróżnicowania rzeczywistość materialna jest niebytem, natomiast byt przysługuje rzeczywistości inteligibilnej. Platońskie Idee są bytami; rzeczywistość materialna jest niebytem, a kryterium podziału znów stanowi możliwość ludzkiego poznania.

Ostatnie - piąte zróżnicowanie bytu i niebytu w systemie Eriugeny nie posiada typowo poznawczego kryterium, lecz, wprost przeciwnie,

15 Platon, Timajos w Dialogi tom II, Kęty 2005, 677.

16 Eriugena, Komentarz z Homilia, dz. cyt., 69. 
odnosi się do kryteriów moralnych, które dotyczą przede wszystkim sumienia. Piąty podział dotyczy ludzi, w przypadku których można orzec, że są wówczas, gdy są dobrzy. Byt człowieka manifestuje się, gdy człowiek jest dobry, trwa w stanie łaski i pielęgnuje w sobie pierwotne podobieństwo do Boga. „Piąty sposób jest tym, który rozum dostrzega jedynie w naturze ludzkiej. Natura ludzka, kiedy przez grzech porzuciła godność obrazu Bożego, w której istniała w sposób właściwy, słusznie utraciła swój byt i dlatego mówi się o niej, że nie jest. Gdy zaś odnowiona łaską Jednorodzonego Syna Bożego powraca do stanu swojej substancji, w której została stworzona na obraz Boży, wtedy zaczyna być, kiedy zaczyna żyć w tym, który został ustanowiony według Bożego obrazu"17. Utracony z powodu grzechu obraz Boga w człowieku można znów niejako uzyskiwać i pielęgnować, bo Bóg Niebyt daje możliwość dostąpienia łaski, przez którą człowiek może uzyskać byt. Człowiek posiadający wolną wolę sam może określić siebie, dokonując dwóch możliwych wyborów. Może zamazywać w sobie podobieństwo do Boga i wówczas podąża w stronę niebytu podobnego do niebytu materii, która jest niebytem z powodu braku. Analogicznie, człowiek również będzie niebytem z powodu braku podobieństwa do Boga. Może również skorzystać z łaski i dobrze postępując troszczyć się o utracone przez grzech podobieństwo do Boga, pielęgnować je i stanowić byt. W tym zróżnicowaniu człowiek jest bytem o tyle, o ile jest podobny do doskonałego Niebytu.

Podział na byt i niebyt w systemie Eriugeny wyraża się w próbie ujęcia całej rzeczywistości w tych dwóch kategoriach. Pomimo charakterystycznego rozumienia pojęć bytu i niebytu oraz języka, które może wprowadzać w błąd, cała rzeczywistość, jakby na przekór

17 Tenże, Periphyseon, Księga I, 71 oraz 70 za Eriugena, Periphyseon, liber primus: „Quintus modus est quem in sola humana natura ratio intuetur, quae divinae imaginis dignitatem in qua proprie substetit peccando deseruit merito esse suum perdidit, et ideo dicitur non esse. Cum vero inigeniti filii dei gratia restaurata ad pristinum suae sucstantiae statum in qua secundum imaginem dei condita est reducitur, incipit esse, cum in eo qui secundum imaginem dei conditus est incipit vivere". 
ograniczonym możliwościom ludzkiego poznania, została ujęta w tej ontologii. Humanizm rozumiany jako troska o dobro człowieka stał się bardzo istotnym elementem całego systemu filozoficznego, ponieważ ludzkie ograniczenie poznawcze stało się istotnym kryterium ontologicznym właśnie dlatego, że jest ludzkie. Eriugena jakby chciał pokazać, że pomimo słabości człowiek może i powinien zabiegać o zrozumienie nawet wówczas i tym bardziej wówczas, gdy przedmiotem poznania jest rzeczywistość niepoznawalna.

\section{WYBRANE KATEGORIE W ONTOLOGICZNYM PODZIALE}

Zgodnie z zaproponowanym przez Eriugenę podziałem całej rzeczywistości na byt i niebyt; podziałem bytu i niebytu na pięć sposobów interpretacji ${ }^{18}$ oraz przyjętym kryterium tego podziału zasadnym wydaje się dokonanie analizy, czym ten podział skutkuje w systemie Jana Szkota w kontekście takich kategorii, jak Bóg, przyczyny rzeczy, człowiek, rzeczy zmysłowe i materia. Byt i niebyt mają w dokonanych zróżnicowaniach różne znaczenia. W zależności od zróżnicowania byt może posiadać konotację pozytywną, związaną z jakąś doskonałością lub negatywną, związaną z faktem, że w porządku rzeczywistości pozostaje usytuowany niżej niż porządki doskonalsze. Podobnie jest $\mathrm{z}$ niebytem, który raz uzyskuje status niebytu $\mathrm{z}$ powodu doskonałości, innym razem może uzyskać ten sam status z powodu braku doskonałości lub braku porządków niższych wobec niego. Chodzi tu oczywiście o status terminologiczny, ponieważ w realnym istnieniu doskonały Niebyt jest najdalej od niedoskonałego niebytu, co najlepiej ukazuje przykład Boga i materii pierwszej.

Bóg w systemie Eriugeny zawsze jest pozytywnym Niebytem. Zgodnie ze zróżnicowaniem pierwszym przyczynami takiego określenia Boga jest fakt, że: a) wymyka się On ludzkiemu poznaniu, b) jest absolutnie doskonały, c) jako jedyny podsiada realne istnienie, d)

18 Zob. tenże, Periphyseon, Księga I, dz. cyt., 63. 
jako Niebyt warunkuje istnienie bytów, sam będąc ponad wszelkim bytem, e) sam siebie nie pojmuje, nie definiuje i nie ogranicza, przez co pozostaje zawsze niepojęty, niedefiniowalny i nieograniczony. Zgodnie ze zróżnicowaniem drugim, przyczynami takiego określenia Boga jest fakt, że w hierarchicznej strukturze rzeczywistości Bóg nie potwierdza swoim istnieniem niczego wyższego od siebie i jednocześnie nie pozwala, by pojęły Go porządki niższe od Niego, co oczywiście w kontekście zróżnicowania pierwszego jest w ogóle niemożliwe, skoro sam Bóg siebie nie pojmuje. Niepoznawalność, realne istnienie, nieograniczoność i absolutna doskonałość są uzasadnieniem dla ujęcia Boga jako Niebytu i w żadnym z pięciu zróżnicowań bytu i niebytu Bóg innego statusu nie posiada.

Inaczej jest z przyczynami rzeczy. Posiadają one zawsze konotację pozytywną, lecz w zależności od zróżnicowania są pozytywnymi niebytami lub pozytywnymi bytami. W pierwszym zróżnicowaniu przyczyny rzeczy są bytami, ponieważ jako racje i istoty rzeczy zostały tak stworzone, czy tak ustanowione przez Boga, że są do Niego podobne w kontekście ludzkich możliwości poznawczych. Przyczyny wymykają się ludzkiemu poznaniu - wymykają się wszelkiemu rozumowi, intelektowi i zmysłowi z powodu swojej wzniosłej natury, którą otrzymały od Boga. Zgodnie z drugim podziałem przyczyny są bytami dla Boga, który stanowi wobec nich porządek wyższy w hierarchicznej strukturze rzeczywistości, a ponieważ Bóg zawsze jest Niebytem, więc przyczyny są bytami. W trzecim zróżnicowaniu przyczyny są niebytami dla ludzi, ponieważ jako takie funkcjonują, zdaniem Eriugeny, w ludzkim ujęciu. Źródłem przyczyn jest sam Bóg, więc dla Boga, który sam jest Niebytem, przyczyny są bytami poprzez fakt, że On jest ich źródłem oraz poprzez fakt, że On jako ich źródło poznał je. Dla ograniczonego ludzkiego poznania przyczyny są niebytami, z których wyłaniają się poznawalne dla człowieka byty. Zachodzi tu pewna analogia uwarunkowana możliwościami poznawczymi człowieka. Z Niebytu Boga wyłoniły się przyczyny byty, natomiast z niebytów przyczyn wyłoniły się byty - poznawalne przez 
człowieka rzeczy. W czwartym zróżnicowaniu przyczyny również są bytami, ponieważ należą do rzeczywistości inteligibilnej, co oznacza, że należą do bytu. Przemawia za tym fakt, że trwają one niezmiennie, więc w procesie rozumowania mogą zostać pojęte intelektem. W tym miejscu stanowisko Eriugeny wydaje się sprzeczne z zróżnicowaniem trzecim, jednak ta pozorna sprzeczność wynika raczej z założonych kryteriów zróżnicowań, a nie $\mathrm{z}$ ich istoty. W czwartym zróżnicowaniu przyczyny, tak jak Platońskie Idee, posiadają byt, bo są wieczne i niezmienne w przeciwieństwie do rodzących się, zmieniających się i ginących rzeczy zmysłowych - w przeciwieństwie do zdarzających się w rzeczywistości zmysłowej procesów, które ludzie nazywają rzeczami.

W rzeczywistości podzielonej na byt i niebyt człowiek zgodnie z pierwszym zróżnicowaniem jest usytuowany poniżej poziomu Boga i przyczyn rzeczy, więc poniżej Niebytów, co powoduje, że sam jest bytem. Człowiek znajduje się jednocześnie powyżej materii pierwszej, co potwierdza, że ten, którego ograniczone możliwości poznawcze stały się istotnym kryterium całego podziału na byty i niebyty, sam jest bytem. Dla Boga człowiek jest bytem, ponieważ Bóg zna człowieka - poznał człowieka, a dla siebie samego człowiek również jest bytem, który powinien poznawać siebie, choć nie wiadomo, czy człowiek jest zdolny do ostatecznego poznania siebie. Można być sceptycznym w tej kwestii, lecz samo przyjęcie tego zadania i trwanie w tym procesie poznania już wydaje się uprawniać do przyznania, że w tym kontekście człowiek jest bytem. Zgodnie z drugim zróżnicowaniem człowiek również jest bytem, ponieważ jest poznany przez porządek wyższy w hierarchicznej strukturze rzeczywistości, z której ten podział wynika, oraz jest poznawany przez siebie samego. Jednocześnie jednak człowiek jest niebytem, o ile nie pozwala, by poznawały go porządki niższe, co jakby uzależniało ludzki niebyt od woli samego człowieka pozwalającego się poznać lub nie pozwalającego na poznanie siebie przez porządki niższe. Człowiek w tym zróżnicowaniu jest niebytem również mimo swojej 
woli, ponieważ istnieją takie porządki niższe, które niezależnie od człowieka nie moga go poznać. Zgodnie z trzecim zróżnicowaniem żyjący w świecie ludzie są bytami, ponieważ w tym świecie zaistnieli - dali się poznać w określonym miejscu i czasie, co jednocześnie oznacza, że wcześniej byli niebytami, bo istnieli potencjalnie w swych przyczynach. Ludzie uaktualnieni w świecie są bytami, natomiast ci, którzy mają się dopiero narodzić, jeszcze są niebytami, ale już są. W czwartym zróżnicowaniu ujawnia się pewien problem z człowiekiem, ponieważ jeśli ograniczymy go tylko do materii, to będzie on niebytem z powodu pewnych braków. W tym zróżnicowaniu byt przysługuje tylko temu, co wieczne i niezmienne. W tym kontekście ludzkie ciało jest niebytem, jednak Eriugena absolutnie nie ogranicza człowieka do cielesnej powłoki. Złożoność człowieka powoduje, że ciało kieruje go w stronę niebytu naznaczonego brakiem, a to, co duchowe, kieruje go w stronę tego, co wieczne i niezmienne, bo stamtąd pochodzi jego natura. Tak człowiek jest bytem i niebytem jednocześnie. Sytuacja ta zostaje potwierdzona w piątym zróżnicowaniu, które dotyczy tylko człowieka i pozbawione jest kryteriów poznawczych. Wynika ono z kryteriów etycznych, zgodnie z którymi człowiek jest bytem wówczas, gdy żyje moralnie i jest dobry i trwa w Bożej łasce i pielęgnuje w sobie podobieństwo do Boga. Ten sam człowiek może jednak stać się niebytem, gdy zrezygnuje z moralności i świadomie będzie zamazywać Boże podobieństwo w sobie.

W podziale rzeczywistości na byt i niebyt zmysłowy świat rzeczy złożonych $\mathrm{z}$ formy i materii oraz materia pierwsza zgodnie $\mathrm{z}$ pierwszym zróżnicowaniem sytuują się oczywiście poniżej poziomu przyczyn rzeczy, co powoduje, że rzeczy złożone z formy i materii są bytami znajdującymi się jednocześnie powyżej samej materii pierwszej, która pozbawiona formy jest niepoznawalnym niebytem. Zgodnie z drugim zróżnicowaniem rzeczy są bytami, ponieważ są poznawane przez porządek wyższy w hierarchicznej strukturze rzeczywistości oraz jednocześnie są niebytami, bo istnieje jeszcze sama materia pierwsza bez formy i ta materia stanowi taki porządek niższy, 
który nie poznaje wyższego porządku rzeczy. Zgodnie z trzecim zróżnicowaniem rzeczy zmysłowe są bytami, ponieważ zaistniały $\mathrm{w}$ świecie umożliwiając poznanie w miejscu i czasie, co jednocześnie oznacza, że wcześniej były niebytami, bo istniały potencjalnie w swych przyczynach. W czwartym zróżnicowaniu rzeczy z powodu braków są niebytami, ponieważ byt przysługuje tylko temu, co wieczne i niezmienne. Rzeczy powstają, trwają w nieustannej zmianie i giną, więc są niebytami.

W zaproponowanym przez Eriugenę podziale rzeczywistości na byty i niebyty można dostrzec paradoksy, których źródłem wydają się być kryteria zaproponowanych zróżnicowań, niedoskonały język ludzki oraz fakt, że filozof podając określoną definicję bytu, za niebyt uważa to, co jest negacją tego bytu. Paradoksy wynikające z podziału rzeczywistości na byt i niebyt oraz dokonaniu pięciu zróżnicowań rozumienia bytu i niebytu zamieszczono w poniższych tabelach.

\begin{tabular}{|c|c|c|c|c|c|}
\hline Kategoria & $\begin{array}{c}\text { Zróżnicowa- } \\
\text { nie I }\end{array}$ & $\begin{array}{c}\text { Zróżnicowa- } \\
\text { nie II }\end{array}$ & $\begin{array}{c}\text { Zróżnicowa- } \\
\text { nie III }\end{array}$ & $\begin{array}{c}\text { Zróżnicowa- } \\
\text { nie IV }\end{array}$ & $\begin{array}{c}\text { Zróżnicowa- } \\
\text { nie V }\end{array}$ \\
\hline Byt & Człowiek & Przyczyny & Przyczyny & Przyczyny & Człowiek \\
& Rzeczy & rzeczy, & rzeczy, & rzeczy, \\
& zmysłowe & Człowiek, & Człowiek, & Człowiek & \\
& & Rzeczy & Rzeczy & & \\
& & zmysłowe & zmysłowe & & \\
\hline \multirow{2}{*}{ Niebyt } & Bóg, & Bóg & Przyczyny & Człowiek & Człowiek \\
& Przyczyny & Człowiek & rzeczy, & Rzeczy & \\
& rzeczy & Rzeczy & Człowiek, & zmysłowe & \\
& Materia & zmysłowe & Rzeczy & & \\
& pierwsza & Materia & zmysłowe & & \\
& & pierwsza & & & \\
\hline
\end{tabular}

Tab. 1: Byty i niebyty w zróżnicowaniach Eriugeny

Powyższa tabela ukazuje, jak Eriugena w autorskim podziale wszystkiego na byt i niebyt zamyka istotne dla filozofii pojęcia Boga, 
przyczyn rzeczy, człowieka, świata rzeczy zmysłowych i materii pierwszej.

\begin{tabular}{|c|c|c|c|c|c|}
\hline $\begin{array}{c}\text { Zróżnico- } \\
\text { wanie }\end{array}$ & Bóg & $\begin{array}{c}\text { Przyczyny } \\
\text { rzeczy }\end{array}$ & Człowiek & $\begin{array}{c}\text { Rzeczy } \\
\text { zmysłowe }\end{array}$ & $\begin{array}{c}\text { Materia } \\
\text { pierwsza }\end{array}$ \\
\hline I & Niebyt & Niebyt & Byt & Byt & Niebyt \\
\hline II & Niebyt & Byt & Byt / Niebyt & Byt / Niebyt & Niebyt \\
\hline III & & Byt / Niebyt & Byt / Niebyt & Byt / Niebyt & \\
\hline IV & & Byt & Byt / Niebyt & Niebyt & \\
\hline V & & & Byt / Niebyt & & \\
\hline
\end{tabular}

Tab. 2: Pięć kategorii w pięciu zróżnicowaniach

Powyższa tabela ukazuje, iż najmniej złożona jest koncepcja Boga i materii pierwszej. Przyporządkowanie przyczyn rzeczy jest ściśle związane z kryteriami poznawczymi oraz ich cechami własnymi wiecznością i niezmiennością. Problem z przyporządkowaniem człowieka wynika $z$ kryteriów poznawczych i jego aktualizacji w świecie lub istnieniu potencjalnym $w$ przyczynach oraz $z$ kryteriów etycznych związanych z moralnym życiem i zachowywaniem podobieństwa do Boga. Podobnie jest $\mathrm{z}$ rzeczami zmysłowymi. Paradoksy wynikaja tu $\mathrm{z}$ kryteriów poznawczych i aktualizacji $\mathrm{w}$ świecie lub istnieniu potencjalnym w przyczynach oraz $\mathrm{z}$ cech własnych - powstawaniu, zmianie i ginięciu.

\section{ZAKOŃCZENIE}

Cała rzeczywistość zostaje ujęta w systemie Eriugeny w kategorii bytu i niebytu. Dzieje się tak na przekór ograniczonym możliwościom ludzkiego poznania, dzięki charakterystycznemu dla Eriugeny rozumieniu bytu i niebytu, choć język opisu tej ontologii może wprowadzać w błąd i stanowić źródło nieporozumień. Dla dobra człowieka, 
filozof usiłuje wyjaśnić niemożliwe do wyjaśnienia problemy, co powoduje, że humanizm rozumiany jako troska o dobro, szczęście, rozwój i zbawienie człowieka staje się bardzo istotnym elementem całego systemu filozoficznego. Ograniczone ludzkie możliwości poznawcze stanowią ważne kryterium ontologicznego podziału. Eriugena jakby chciał wskazać, że człowiek, pomimo swej słabości, może i powinien zabiegać o zrozumienie spraw najważniejszych nawet wówczas, gdy rzeczywistość, ku której się kieruje, jest rzeczywistością niepoznawalną. Rozważając tak istotne kategorie, jak Bóg, przyczyny rzeczy, człowiek, rzeczy zmysłowe i materia, Eriugena dochodzi do paradoksów, które wynikają z przyjętych kryteriów poznawczych, $\mathrm{z}$ zaistniałej aktualizacji $\mathrm{w}$ świecie, $\mathrm{z}$ potencjalnego istnienia w przyczynach oraz z takich przypadłości, jak powstawanie i przemijanie. Poszukując pierwszych odniesień do tak oryginalnego podziału rzeczywistości na byty i niebyty Agnieszka Kijewska zwraca uwagę, że autorską koncepcję niebytu Eriugena sformułował już dziele $O$ Predestynacji ${ }^{19}$, a więc przed powstaniem Periphyseonu i Homilii. W kontekście uznania Boga za Niebyt autorka uważa, że inspiracji do takiego ujęcia Boga dostarczyły Eriugenie pisma Mariusza Wiktoryna i Pseudo-Dionizego Aeropagity ${ }^{20}$.

\section{BIBLIOGRAFIA}

Eriugena Jan Szkot, Komentarz do Ewangelii Jana z Homiliq do Prologu Ewangelii Jana, przełożyła: A. Kijewska, ANTYK, Kęty 2000.

Eriugena Jan Szkot, Periphyseon, Księga I, przełożyła, wstępem i komentarzami opatrzyła A. Kijewska, Marek Derewiecki, Kęty 2009.

Kijewska A., Eriugena, Myśli i ludzie, Wiedza Powszechna, Wydanie I, Warszawa 2005.

Benedykt XVI, Pseudo-Dionizy Aeropagita, Audiencja Generalna 14 maja 2008 roku, L'Osservatore Romano (2008)6(304).

19 Zob. A. Kijewska, Eriugena, Wydawnictwo Wiedza Powszechna, Wydanie I, Warszawa 2005, 52.

20 Zob. tamże, 52. 
Benedykt XVI, Jan Szkot Eriugena, Audiencja Generalna 10 czerwca 2009 roku, L'Osservatore Romano (2009)9(316).

Platon, Dialogi tom II, przełożył oraz wstępem i objaśnieniami opatrzył W. Witwicki, Antyk, Kety 2005.

Pseudo-Dionizy Aeropagita, Hierarchia niebiañska IV, 1 w: Pisma teologiczne II, tłumaczenie M. Dzielska, Znak, Kraków 1999.

\title{
ERIUGENA'S ONTOLOGICAL CONCEPT OF REALITY
}

\begin{abstract}
In a 2009 general audience, Benedict XVI offered the short deliberation concerning the thought of Eriugena, whose views were condemned four times. Eriugena's concept was most often viewed in history as a pantheistic vision of reality, contrary to Christianity, or as Christian Neo-Platonism. The article is an attempt to portray Eriugena's ontological vision of reality in the frame of his philosophical system. According to his division of reality into existence and non-existence and the adopted criteria of identity, the article also constitutes an attempt to analyze what this division means for such categories as God, causes of the thing, man, sensory things, and matter. Eriugena's views penetrated into European philosophy and in a subtle, unappreciated way had an influence, and Eriugena himself was not properly understood.
\end{abstract}

Keywords: God, Eriugena, existence, non-existence, Benedict XVI, ontology

\author{
ADAM GRZEGORZYCA \\ grzegorzycaadam@gmail.com \\ Uniwersytet Opolski, Instytut Filozofii \\ Katowicka 89, 45-061 Opole
}

DOI: $10.21697 /$ spch.2016.52.2.03 